\section{Revista de Literatura, História e Memória

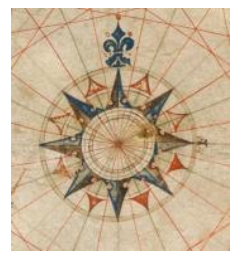

Seção: Pesquisa em Letras no contexto Latino-americano e Literatura, Ensino e Cultura

ISSN 1983-1498

VOL. 16 - No 27 - 2020

U N I O E S T E / CA S C A V E L - p. 326-344

\title{
SÃO GONÇALO DO AMARANTE: A IMAGEM, A REPRESENTAÇÃO, O SAGRADO
}

Saint Gonçalo of Amarante: the image, the representation, the sacred

\section{Arlene Rosa Eustáquio ${ }^{1}$}

RESUMO: A proposta deste artigo é refletir sobre a representação da imagem de São Gonçalo do Amarante na peça $O$ prodígio de Amarante, de Antônio José da Silva, também conhecido como o Judeu. Para isso serão levados em conta, principalmente, os estudos de Carlo Ginzburg sobre o conceito de representação, presentes na obra Olhos de madeira: nove reflexões sobre a distância, mais precisamente no ensaio intitulado Representação: a palavra, a ideia, a coisa. Além disso, a fundamentação teórica deste estudo compreenderá os estudos de Karen Armstrong referentes às questões do mito e de Jerusalém, de Mircea Eliade sobre o sagrado e de Carl Gustav Jung e suas contribuições no que diz respeito aos arquétipos e ao inconsciente coletivo.

PALAVRAS-CHAVE: São Gonçalo do Amarante; Representação; Sagrado, Jerusalém.

ABSTRACT: The purpose of this article is to reflect on the representation of the image of Saint Gonçalo of Amarante in the play for Antonio José da Silva's The Prodigy of Amarante, also known as the Jew. For this, we will take into account, mainly, the studies of Carlo Ginzburg on the concept of representation, present in the book Ey Wooden Eyes: Nine Reflections on Distance, more precisely in the essay entitled Representation: the word, the idea, the thing. In addition, the theoretical underpinnings of this study will include Karen Armstrong's studies of myth and Jerusalem, Mircea Eliade's studies of the sacred, and Carl Gustav Jung's contributions to the archetypes and the collective unconscious.

KEYWORDS: Saint Gonçalo of Amarante; Rrepresentation; Ssacred; Jerusalem.

\section{ANTÔNIO JOSÉ DA SILVA: UM JUDEU HEREGE NA INQUISIÇÃO}

Antônio José da Silva, também conhecido como o Judeu, nasceu no Rio de Janeiro em 08 de maio de 1705. Juntamente com sua família, sofreu os abusos cometidos pela Igreja Católica na época da "Caça às bruxas", tempo em que o Tribunal do Santo Ofício perseguia e punia, muitas vezes com a morte na fogueira, as pessoas consideradas hereges, ou seja, aqueles que eram contrários aos ideais da fé católica. Dines o apresenta da seguinte forma:

Da Silva, Antônio José. Nome de anônimo, heterônimo de joão-ninguém, homônimo da multidão. Diferente é o ferrete da alcunha póstuma: Judeu. Da Silva. Complemento coloquial de adjetivos - doidinho da Silva, desgraçadinho da Silva. O mais prosaico dos sobrenomes e apelidos

\footnotetext{
${ }^{1}$ Professora de Língua Portuguesa e doutaranda em Teoria Literária pela Universidade Federal de Uberlândia.
} 
converteu-se, por artes do idioma, em garantia de qualidades. (DINES, 1992, p. 21).

Antônio José viveu em Portugal durante o reinado de D. João V (1689-1750), que foi marcado pela profunda ligação com a Igreja Católica e pela afirmação da dinastia de Bragança. Além disso, foi uma época de grande desenvolvimento econômico para o país, que enriquecia em decorrência da chegada do ouro que vinha do Brasil. O reinado de D. João, que era mecenas das artes, promoveu o desenvolvimento cultural, criou capelas e conventos suntuosos, como o de Mafra, além de academias literárias e universidades. Apesar disso, todo o conhecimento era submetido ao domínio da Igreja.

Em meados do século XV, como acontecera na Espanha anos antes, foi criado em Portugal o Tribunal do Santo Ofício da Inquisição. A presença dessa instituição na vida do Judeu é de grande relevância, uma vez que Antônio José, além de ser censurado pelo Santo Ofício, perdeu a vida em um Auto de Fé.

Foram criados Tribunais em Lisboa, Coimbra, Évora, Tomar e Porto. Os três últimos foram abolidos por causa dos grandes abusos e corrupção de sua administração. Os demais trabalharam com intensidade até o século XIX. Considerando as proporções do território português, podemos dizer que a Inquisição lusitana ultrapassou em ferocidade e violência a Inquisição espanhola, contrariamente ao que se tem escrito. (NOVINSKY, 1990, p. 36).

O Judeu foi levado juntamente com a família para Portugal em 1712, a fim de prestar contas ao Tribunal do Santo Ofício pelas ditas "práticas judaizantes”, foi perseguido e preso várias vezes, até que em 18 de outubro de 1739, após ser penitenciado, foi morto a garrote em um auto de fé, já que havia abdicado de sua condição de judeu e preferido morrer na lei de Cristo, a fim de não ser queimado vivo. Na obra $O$ judeu em cena, lançada pela Editora da Universidade de São Paulo, EDUSP, em 2005, Alberto Dines faz o seguinte comentário a respeito da vida de Antônio José da Silva:

Viveu apenas 34 anos e na biografia abreviada pela intolerância só constam sufocos e asfixias: não teve direito a uma identidade, viveu abafado pelo anonimato e, para vencer a insignificância de um nome tão corriqueiro que parece homônimo de joão-ninguém, só conseguiu ser reconhecido depois de esganado pela Santa Inquisição - graças à alcunha convertida em pseudônimo. Infamante, por sinal. (DINES, ELEUTÉRIO, 2005, p. 17).

O Judeu encerrava assim uma vida repleta de perseguições, medo e também de uma grande produção teatral. Autor popular, escreveu e produziu várias peças, dentre elas Vida do 
grande D. Quixote de la Mancha e do gordo Sancho Pança, Esopaida ou Vida de Esopo, Os encantos de Medeia, Precipício de Faetonte e Anfitrião ou Júpiter e Alcmena. A maioria delas era encenada no Teatro do Bairro Alto, em Lisboa, e os atores eram bonifrates, gigantes bonecos de cortiça que permitiam a Antônio José dar voz ao seu descontentamento em relação a um governo que, aliado à Igreja, perseguia e matava, de forma absurda, inocentes em nome de Deus.

O prodígio de Amarante foi uma das primeiras peças escritas por Antônio José da Silva, por volta de 1720. Ela versa sobre a vida e os milagres de São Gonçalo do Amarante, santo português considerado casamenteiro pelos devotos católicos. Atualmente, no Porto, em Portugal, existe a Igreja Matriz de Amarante, localizada onde outrora fora a igreja do já extinto Convento Dominicano de São Gonçalo do Amarante, erguida no século XIII. Próximo à igreja, está a Ponte de São Gonçalo, sobre o rio Tâmega, local de peregrinação e visitação, já que se transformara em Monumento nacional. Assim, Antônio José, certamente, pesquisou a fundo a vida do santo a fim de escrever sua peça.

Em O prodígio de Amarante, São Gonçalo, percebendo que poucas pessoas compareciam a sua igreja, decide ir a Jerusalém a fim de se penitenciar por seus pecados e assim, receber o perdão de Deus, que restabeleceria os fieis de volta a sua igreja. Adepto da caridade, o santo ajudava os desempregados, o mendigos, cegos e coxos que iam até ele solicitar-lhe auxílio. Assim, toda a renda de sua igreja era revertida a favor dos mais necessitados, sob os protestos do truão Guarin, que é a voz cômica da peça:

\section{[...]}

S. Gonçalo: Tome irmão, este dobrão.

Cego: Um dobrão, senhor, me dás?

S. Gonçalo: Desculpa-me não ser mais.

Guarin: Que se transforme em carvão...

(SILVA, 2005, p. 115).

Quando parte para Jerusalém, o sobrinho Antônio, que deveria tornar-se padre, passa a viver "em pecado" com Rosaura e a usufruir da renda da igreja em proveito próprio. Guarin, o bobo da corte, responsável pelas críticas ácidas à igreja e aos costumes da época, tudo observa e sempre espera o momento exato de se expressar. Quando São Gonçalo retorna de Jerusalém e constata o que foi feito por Antônio, este lhe dá uma surra e o expulsa de sua casa, tendo o santo que se abrigar nos penedos.

S. Gonçalo: Que é isto, sobrinho? Ignoras

o respeito que me deves? 
Não sabes que sou o dono desta casa? E que sou Abade de juro e propriedade? Com que torpe perdição queres negar o que é meu?

Guarin: Meu amo é Abade intruso.

D. Antônio: Velho caduco inoportuno, do mais louco delírio, vai-te da minha vista, já, que aqui nada tens, que desta casa os bens, é a riqueza que mos dá. (SILVA, 2005, p. 179).

A partir daí, São Gonçalo passa a ver a própria Nossa Senhora e a conversar com os anjos. Até que, na sua última aparição, torna-se turva e esvai-se:

S. Gonçalo: Não encubras, bela aurora, teus raios celestiais.

Enche, senhora, o meu peito com teus divinos matizes.

Seguirei tua vontade, vou procurar sem demora a ordem sagrada de que me dás os sinais. - sai. (SILVA, 2005, p. 201).

Após receber abrigo na Ordem dos Dominicanos, decide que irá construir uma ponte sobre o rio Tâmega, já que muitos de seus fiéis, no intuito de ir vê-lo pregar, morriam afogados nas águas desse rio. Durante um dia de muito trabalho e já terminado o vinho dos trabalhadores, São Gonçalo realiza um milagre: faz brotar vinho dos rochedos. No fim da peça o santo perdoa o sobrinho e Rosaura, convertendo-os à vida no monastério e é elevado aos céus por Nossa Senhora e recebido por São Pedro.

S. Pedro: Oh, Soberano Gonçalo, feliz de ti, que voas nas asas de querubins para a glória suprema. (SILVA, 2005, p. 273)

Sendo São Gonçalo do Amarante o personagem principal da peça $O$ prodígio de Amarante, é interessante refletir sobre a importância do santo para a comunidade católica. Antes disso, porém, faz-se necessário pensar a escolha de Antônio José para um enredo que fala sobre um santo, e um santo de origem portuguesa em pleno período de censura e 
desmandos por parte da Igreja. Essa poderia ter sido uma estratégia do Judeu que, tendo visto os sofrimento dos pais e outros familiares, provavelmente já considerava seu triste destino. Por esse motivo, usando de sua inteligência, teria tentado agradar a seus algozes, para que assim, sem despertar muitas suspeitas, pudesse levar ao Teatro do Bairro Alto suas próximas peças, em que a crítica ao governo, à Igreja e aos costumes da época sempre ficava evidente.

Certamente, por ser considerada dentre sua obra dramática a mais "inocente" das peças, talvez por ser a primeira, há de se pensar que tal ingenuidade possa ter sido, sobretudo, um golpe de astúcia de Antônio José, a fim de passar despercebido pelos órgãos da censura. No entanto, o próprio Victor Eleutério, responsável pelo lançamento da obra bilíngue, em parceria com Dines, não cogitou essa hipótese:

Em El Prodigio de Amarante a trama é fraca e não atrai os comediantes de passagem pela Casa dos Bonecos da Rua Rosa. Não contém ainda nem a forma nem a graça que Antônio José da Silva irá dar e instilar nas obras que posteriormente escreveu. Teatralmente não tem força, embora desvende já determinadas características tão caras ao seu autor, particularmente um certo tacto a montar a ideia, originalidade a expressá-la e o recurso tão frequente ao neologismo. Com tais elementos investirá contra os costumes ridículos do seu tempo, fazendo uso de um tipo de sátira corrosiva que não poupará patrões da cultura, jesuítas e a guardiã da "pureza" da religião, a Inquisição, envolvendo nessa acrimônia sátira os amores freiráticos do rei. (ELEUTÉRIO, 2005, p. 50).

São Gonçalo, como todo santo, é considerado um intermediário entre Deus e o homem. Sua imagem ora é representada por um padre de batina, crucifixo e viola, ora é representada por um homem com vestimentas de camponês, calção, meias pretas e viola na mão. As peripécias vividas pelo santo na peça de Antônio José, e que povoam o imaginário de seus fiéis até os dias de hoje, sustentam a fé do povo, mesmo não sendo possível provar se tais acontecimentos foram ou não reais.

Dessa forma, por meio das reflexões do historiador italiano Carlo Ginzburg, que teve um aspecto comum com a vida de Antônio José da Silva (ambos judeus nascidos em países cristãos), Procurar-se-á alcançar o que representa a imagem de São Gonçalo do Amarante. Antes disso, faz-se necessário compreender a significação do título da obra que fará a fundamentação teórica deste artigo: Olhos de madeira: nove reflexões sobre a distância, de Ginzburg.

Aqui o autor fala do distanciamento em que precisamos nos colocar a fim de analisarmos questões muito discutidas, mas que não estão de todo explicadas, como o mito, a representação e mesmo as diversidades raciais, linguísticas, religiosas e sociais que separam 
os seres humanos. É assim que será discutida a questão da representação no ensaio Representação: a palavra, a ideia, a coisa, de forma distanciada, porém, considerando, sobretudo, a reflexão e a crítica.

\section{A IMAGEM E A REPRESENTAÇÃO DE SÃO GONÇALO DO AMARANTE}

Para o desenvolvimento do presente estudo, é preciso levar em conta os conceitos de imagem e de representação, até que se chegue à compreensão do que representa a imagem de São Gonçalo do Amarante. A palavra imagem é originária do latim - imago - e significa cópia da realidade. Quando se fala em imagem, e não somente em imagens sacras, fala-se do próprio homem, pois é sabido que desde a Antiguidade, ela é a expressão da cultura humana. Por isso, muito antes do surgimento da escrita, as imagens rupestres já apareciam nas cavernas, tamanha a importância para o homem de representar de outras formas a realidade que se apresentava diante de si.

Ademais, o conceito de representação complementa o conceito de imagem. Ginzburg, em seu ensaio Representação: a palavra, a ideia, a coisa, define representação da seguinte forma:

Por um lado, a "representação" faz as vezes da realidade representada e, portanto, evoca a ausência; por outro, torna visível a realidade representada e, portanto, sugere a presença. Mas a contraposição poderia ser facilmente invertida: no primeiro caso, a representação é presente, ainda que como sucedâneo; no segundo, ela acaba remetendo por contraste, à realidade ausente que pretende representar. (GINZBURG, 2001, p. 86).

Ginzburg considera que a imagem é ao mesmo tempo presença e sucedâneo de algo que não existe. Ele também deixa claro que definir representação é uma tarefa difícil, e que o termo vem sendo usado de forma tão popular, que muitas vezes não se reflete verdadeiramente sobre o que ele significa.

Além disso, Ginzburg (2001) defende a ideia de que o significado do termo deve ser acompanhado de uma reflexão mais profunda dentro da historiografia, já que suas possíveis definições perpassam o campo do imaginário, da mitologia e da memória, dentre outros. Por isso, o autor recorre à Idade Média e complementa os estudos de Roger Chatier (1991) no que tange à representação, afirmando que ela assemelha-se à verdade, mas para isso faz-se necessário que haja provas que forneçam um certo grau de confiabilidade. Sendo assim, é preciso considerar que a representação fica no lugar do real, apenas guardando semelhanças 
com este, nunca o substituindo.

Em seu estudo, Ginzburg traça um percurso, desde a Idade Média, até chegar ao estudo das imagens sacras. Primeiramente o autor cita os catafalcos vazios dos funerais régios que remontam a 1291, na Espanha. Também discorre sobre os manequins dos reis nos funerais, feitos de couro, cera ou madeira, que datam de 1327, na Inglaterra. Estes, exibidos ao lado do cadáver do soberano, propagavam a teoria jurídica do duplo corpo do rei, e era também uma forma de eternizá-lo diante dos seus súditos. Na Roma antiga e também na Inglaterra e na França dos XIII e XIV, realizava-se também o funeral das imagens:

Em ambos os casos, eram seguidos dos funerais das imagens, ou seja, de um rito não apenas definitivo, mas eternizador. O imperador era consagrado deus; o rei, em virtude da afirmação da perenidade da função, não morria nunca. As imagens imperiais de cera e as efígies reais, que consumavam a morte dos imperadores como processo social, equivaliam, num plano diferente, às múmias ou aos esqueletos. (GINZBURG, 2001, p. 89).

Por fim, temos a definição de kolossós, que significa, de forma precisa, "estatuetas funerárias, substitutos rituais, duplos que tomam o lugar dos ausentes e continuam sua existência terrena" (GINZBURG, 2001, p.92). Conclui-se que os catafalcos vazios, os manequins dos reis e as estátuas eram formas de perpetuar a vida, de dar à morte uma outra significação, já que nunca foi possível vencê-la. A partir dessas imagens, e do que consequentemente elas representam, é possível chegar à representação das relíquias dos santos e, finalmente, à representação da imagem de São Gonçalo do Amarante, que se apresenta na peça como um santo ditoso, capaz de agradar até mesmo Nossa Senhora:

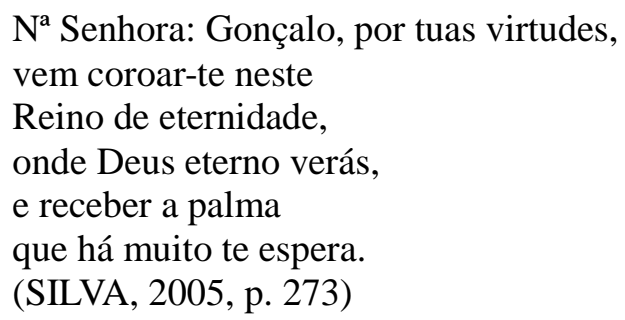

Ginzburg (2001) considera o fato de que a valorização, tanto das relíquias dos santos como de suas imagens, pudessem vir a ser interpretadas como adoração, e, portanto, confundidas com o culto aos deuses pagãos gregos e romanos. Tal atitude, para os cristãos, seria considerada como idolatria e isso seria inadmissível dentro dos fundamentos da religião católica. Assim, durante a Idade Média, prevalece o que Ginzburg (2001) explica como sendo "medo e desvalorização das imagens". No entanto, a palavra veneração e o dogma da 
transubstanciação, ou seja, da presença de Cristo na eucaristia, substituíram o que poderia ser adoração das relíquias e das imagens de santos:

À luz da formulação do dogma da transubstanciação não se pode falar simplesmente de "contato", mas sim de presença no sentido mais forte do termo. A presença de Cristo na hóstia é, de fato, uma superpresença. Diante dela, qualquer evocação ou manifestação do sagrado - relíquias, imagens empalidece, pelo menos em teoria. (Na prática, as coisas são diferentes) (GINZBURG, 2001, p. 102).

Nesse excerto, Ginzburg chama a atenção para o que foi tido como golpe de mestre da Igreja Católica: a veneração das imagens substitui o que poderia ser interpretado como adoração e idolatria. Além disso, com o dogma da transubstanciação, o corpo de Cristo deixa de ser apenas representação e passa a ser uma realidade, em outras palavras, a hóstia não mais representa o corpo de Cristo, ela é o corpo de Cristo.

Podemos concluir que, para a comunidade católica, a imagem dos santos nunca deixou de ser a representação de seres celestes, uma cópia do que estaria no céu. Ela não é o santo, mas o representa. Dessa forma, passaremos a verificar o que representa a imagem de São Gonçalo do Amarante para seus fiéis: vista como um benfeitor, um elo entre o Céu e a Terra, como se vê, iluminado e repleto de graças:

\author{
Coro: Vem Gonçalo venturoso, \\ aonde já te espera, \\ com claros resplendores, \\ a glória sempre formosa. \\ Recebe a coroa \\ que o céu já te concede \\ em prêmio soberano \\ de tua excelsa virtude. \\ (SILVA, 2005, p. 271).
}

Percebe-se que as imagens sacras são produtos de um tempo histórico, cultural e político determinado, mas que se mantêm como símbolo de fé e devoção no presente, sem nunca perder seu lado misterioso:

Retirado da vida religiosa propriamente dita, o sagrado celeste permanece ativo por meio do simbolismo. Um símbolo religioso transmite sua mensagem mesmo quando deixa de ser compreendido, conscientemente, em sua totalidade, pois um símbolo dirige-se ao humano integral e não apenas à sua inteligência. (ELIADE, 1992, p. 109). 
Para o indivíduo que crê na imagem como uma representação de um ser sagrado, pressupõe-se que, entre ele e a imagem, estabeleça-se uma relação de identificação. Por isso, determinados santos são tidos como protetores dos motoristas, das mulheres grávidas, das crianças, dos médicos, etc. Tais imagens possuem uma função simbólica e estética capaz de produzir sensações e emoções diferentes em cada sujeito, de acordo com a vivência de cada um.

Sobre o poder da imagem, Ginzburg alertou que "no âmbito das imagens se insinua uma nova hierarquia, que remonta à tradição judaica: as estátuas são muito mais perigosas que as pinturas, uma vez que servem de incentivo à idolatria." (GINZBURG, 2001, p. 98). Aqui o autor chama a atenção para o fato de as imagens servirem para manipular a fé cristã, ao mesmo tempo em que elas lembrariam a adoração aos deuses pagãos.

Com a inserção do catolicismo no Brasil, a partir do ano de 1549, principalmente por meio da Ordem dos Jesuítas, os portugueses trouxeram para o país a devoção a São Gonçalo do Amarante. A história do santo é desprovida de certezas, alguns historiadores até mesmo questionam sua existência.

Provavelmente, o santo nasceu em 1187, em Portugal e morreu na cidade de Amarante em 10 de janeiro de 1254. Em 1561 tornou-se beato e seu processo de canonização nunca chegou a ser finalizado. Apesar disso, em 10 de julho de 1671 o Papa Clemente X estendeu seu culto a Portugal. O dia 10 de janeiro é considerado o dia de São Gonçalo, data instituída pelo Papa Julio III (1550-1554). Consta que o santo viajou a Roma e Jerusalém, e que, após um momento de reflexão sobre a própria vida, passou a converter pecadores e a operar supostos milagres. É justamente essa versão da história do santo que é contada na pela de Antônio José da Silva.

Gonçalo foi contemporâneo de Santo Antônio e a ele também é atribuída a fama de casamenteiro. Além disso, é considerado protetor dos violeiros e muitos fiéis se apegam a ele durante as enchentes.

No Brasil, principalmente nos estados de São Paulo, Minas Gerais, Goiás, Bahia, Alagoas e Pernambuco, ainda são muitos comuns as festas realizadas em homenagem ao santo, a fim de servirem como pagamento por uma graça recebida. A festa pode ser realizada em qualquer época do ano e é sempre caracterizada pela presença dos rezadores e representantes da Igreja, como o padre, além de prevalecerem as orações, a musicalidade e a dança coreografada, acompanhada pelo som dos violões, violas e pandeiros.

A São Gonçalo havia sido dada a tarefa de entregar os órgãos genitais externos às mulheres e quando aqui chegou encontrou os homens e mulheres em festa e na falta de 
violeiros que continuassem a tocar ofereceu seus préstimos (VENDRAMINI, 1976, p. 46). Por isso, tanto em Portugal como no Brasil, o santo, além de festeiro, também é considerado protetor da fertilidade humana e há registros de que fazia parte das danças a lubricidade e a grosseria nas letras das canções, geralmente obscenas e carregadas de simbologia erótica. Por isso, o caráter profano da festa, que tanto desagradava a Igreja Católica.

Santos (2004) chama a atenção para o fato de que a festa em homenagem a São Gonçalo teria origem pagã:

A festa de São Gonçalo (...) tem a particularidade de conservar aspectos dos rituais que assinalam um tempo de renovação. A festa que coincide pela via do calendário com a "festa de Jano", evoca o Deus romano que é representado com dois rostos que se opõem, um olhando para a frente e outro olhando para trás. Se tivermos em mente esta representação, que aponta para abertura, reinício das coisas e as habituais características da Idade de Ouro atribuídas ao reinado de Jano, tais como a idéia de abundância talvez possamos compreender melhor a associação entre São Gonçalo de Amarante e elementos contidos no seu ritual de fertilidade tanto em Portugal, quanto no Brasil (SANTOS, 2004, p. 226).

É importante compreender o que representa para os fiéis católicos a imagem e a história de São Gonçalo. Pelo fato de haver sido difundida a história de que o santo, aos sábados, vestia-se de mulher, cantava e dançava a noite toda com prostitutas, para que assim elas não caíssem em tentação no domingo, ele é visto como um santo festeiro e alegre, capaz de converter as prostitutas e incapaz de discriminar as pessoas. Como é certo considerar que o homem sempre se expressou por meio de representações, desde os tempos mais remotos, chega-se à conclusão que muitos fiéis identificam-se com o santo, sobretudo em virtude de sua tolerância, compreensão e bondade.

É importante salientar, mais uma vez, que as imagens sacras, consciente ou inconscientemente, representam uma mediação visível entre o homem e o sagrado, capazes de modificar suas relações sociais:

O sagrado é o real por excelência, ao mesmo tempo poder, eficiência, fonte de vida, fecundidade. $\mathrm{O}$ desejo do homem religioso de viver no sagrado equivale de fato, ao seu desejo de se situar na realidade objetiva, de não se deixar paralisar pela relatividade sem fim das experiências puramente subjetivas, de viver num mundo real e eficiente - e não numa ilusão. Esse comportamento verifica-se em todos os planos de sua existência, mas é evidente no desejo do homem religioso de mover-se unicamente num espaço santificado, quer dizer, num espaço sagrado. (ELIADE, 1992, p. 31).

Sendo assim, muitas pessoas que creem no poder da imagem do santo dirigem-se a ela 
a fim de pedir proteção, principalmente os violeiros, as mulheres já velhas que estão em busca de um casamento ou mesmo as pessoas vítimas de preconceito social, como as prostitutas. Para essas pessoas o santo é o elo que as liga a Deus, é a forma mais segura e confiável de estabelecer um contato com o sagrado.

Faz-se necessário, após o exposto, analisar como a representação do sagrado, na figura de São Gonçalo do Amarante, se revela na peça O prodígio de Amarante. A obra foi escrita, provavelmente, por volta de 1720, foi uma das primeiras peças de Antônio José e até pouco tempo atrás não havia certeza sobre quem seria seu verdadeiro autor. A partir dos estudos de Alberto Dines e Victor Eleutério, a EDUSP, Editora da Universidade de São Paulo, lançou-a, em 2005, em edição bilíngue, juntamente com a comprovação de sua autoria.

A peça inicia-se com Antônio, sobrinho de São Gonçalo, e seu criado, o bobo da corte Guarin, perseguindo duas lindas mulheres: Rosaura e sua dama de companhia, chamada Flora. Antônio enamora-se pela beleza de Rosaura e Guarin apaixona-se pela criada Flora. Enquanto isso, São Gonçalo do Amarante assombra-se ao constatar que poucas pessoas estão frequentando a sua igreja:

S. Gonçalo: Mas que vejo? Ninguém ouve?

É isto pregar no deserto.

Nas glórias temporais

se afundam os pecadores, que não ouvem os clamores que lhes predizem os males. (SILVA, 2005, p. 107).

Inconformado, São Gonçalo sente-se culpado pelo pequeno número de pessoas que buscava a palavra de Deus. Era costume, na época, juntarem-se às portas das igrejas, cegos, coxos, desempregados e mendigos, revelando assim a crise financeira vivida em Portugal no século XVI. São Gonçalo era bom e caridoso, e a todos procurava ajudar, diferentemente do sobrinho, Antônio. É nesse primeiro ato da peça que São Gonçalo, por meio do canto de um cego que está às portas de sua igreja, crê ter recebido um sinal divino:

\author{
Cego: Para Jerusalém caminha \\ Jesus depois de jejuar; \\ logo se põe a pregar \\ sua radiosa doutrina \\ (SILVA, 2005, p. 111)
}

Assim, a fala de São Gonçalo do Amarante revela a decisão que tomara naquele 
momento:

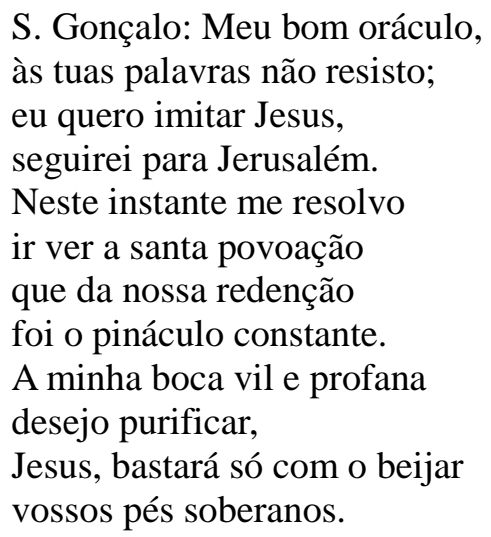

(SILVA, 2005, p. 111).

São Gonçalo acredita que Deus inspira os homens por meio dos humildes. Dessa forma, parte em peregrinação para Jerusalém, deixando seu sobrinho Antônio responsável pela igreja e por cuidar das pessoas mais carentes de Amarante. No entanto, o sobrinho não tem vocação sacerdotal, e passa a viver com Rosaura, ao invés de cuidar dos interesses do tio, que sempre foi um homem caridoso. Além disso, reverte o dinheiro da igreja em proveito próprio, revelando-se corrupto e egoísta.

O destino de São Gonçalo é a Cidade Santa, considerada o local de origem das três grandes religiões monoteístas do mundo: o judaísmo, o cristianismo e o islamismo. De acordo com Karen Armstrong, as pessoas conseguem ver o mesmo símbolo de forma diferente (ARMSTRONG, 2011, p. 11), por isso, Jerusalém, para essas três religiões, embora de maneiras diversas, é um símbolo do sagrado. Jung define que o que chamamos de símbolo é um termo, um nome ou mesmo uma imagem que pode ser familiar na vida diária, embora possua conotações especiais além do seu significado evidente e convencional. Implica alguma coisa vaga, desconhecida, ou oculta para nós (JUNG, 2008, p. 16).

Dessa forma, Jerusalém mantém-se viva no imaginário popular como se fosse uma cidade celeste, é a própria representação do Céu na Terra, quiçá a representação do Jardim do Éden. O símbolo é uma forma de reviver sempre o mito e em Jerusalém revive-se o mito da criação, da origem do mundo.

Em $O$ prodígio de Amarante, Gonçalo acredita que deve reaproximar-se do sagrado, pois só assim conseguirá a salvação para si e seus fiéis. Deus, segundo a Bíblia e o cristianismo, havia se separado do homem após o pecado original. Assim, o contato com a divindade já não era tão fácil e direto. Deus estava no céu, o homem, na terra. Esse era o limite imposto pela divindade, uma espécie de castigo. 
A fim de restabelecer o contato perdido, o homem passou a utilizar imagens da natureza para representar a divindade, como árvores, pedras, o céu, a água. Dessa forma, dentro de um espaço considerado profano, o homem passa a erguer templos, oferecer sacrifícios e construir imagens do que estaria no céu, a fim de poder, de certa forma, ser ouvido por Deus. Na peça, o contato com o sagrado será alcançado por meio da ida de São Gonçalo a Jerusalém:

Tendemos a dizer que determinada coisa é "apenas" um símbolo, essencialmente separado da realidade mais misteriosa que representa. $\mathrm{O}$ mundo pré-moderno, entretanto, não compartilhava essa concepção. Um símbolo fazia parte dessa realidade a que se referia; um símbolo religioso tinha, por conseguinte, o poder de introduzir os devotos no reino do sagrado. (ARMSTRONG, 2011, p. 18).

Mircea Eliade explica que o sagrado manifesta-se de forma diferente das experiências comuns do dia a dia e sempre por meio de objetos profanos, ou seja, que fazem parte do nosso mundo (ELIADE, 1992, p. 17). Dessa forma, é possível chegar à conclusão de que a cidade de Jerusalém para cristãos, judeus e muçulmanos é uma hierofania, ou seja, revela algo que é mais que uma cidade, é o sagrado em si. Jung já dizia que o papel dos símbolos religiosos é dar significação à vida do homem (JUNG, 2008, p. 88), dessa forma, estar em Jerusalém é estar, novamente, na presença da divindade.

Karen Armstrong chama a atenção para o fato de que o sagrado é uma busca constante do ser humano, mesmo na atualidade. A busca pelo divino, pelo mistério e pela transcendência permeia a vida do homem, e muitas vezes quando se estabelece o contato com a divindade, este inspira medo, admiração, entusiasmo, paz ou terror (ARMSTRONG, 2011, p. 14). Quando o personagem São Gonçalo do Amarante sai em peregrinação para Jerusalém, acredita poder reestabelecer a comunhão com o mundo celeste. Ao mesmo tempo em que busca sua iluminação, tentará iluminar a vida de seus fiéis. Aceitando o chamado de Deus, parte ao encontro da plenitude, da reconciliação com o sagrado:

Isso se deve, em parte, a nossa visão de mundo como um vale de lágrimas. Somos vítimas de desastres naturais, mortalidade, extinção, injustiça, crueldade. A busca religiosa geralmente começa com a constatação de que alguma coisa deu errado, de que, como disse Buda, "a existência é errônea". (...) Parece que nos falta alguma coisa, que nossa existência é fragmentada e incompleta, que a vida não devia ser assim e que perdemos algo essencial ao nosso bem-estar - ainda que tenhamos dificuldade para explicar isso racionalmente. (ARMSTRONG, 2011, p. 15). 
Desse modo, São Gonçalo parece penitenciar-se, aos olhos de Deus considera-se um pecador. Acredita que, por seus pecados, não é digno da misericórdia divina, por isso sua igreja constantemente perde fieis:

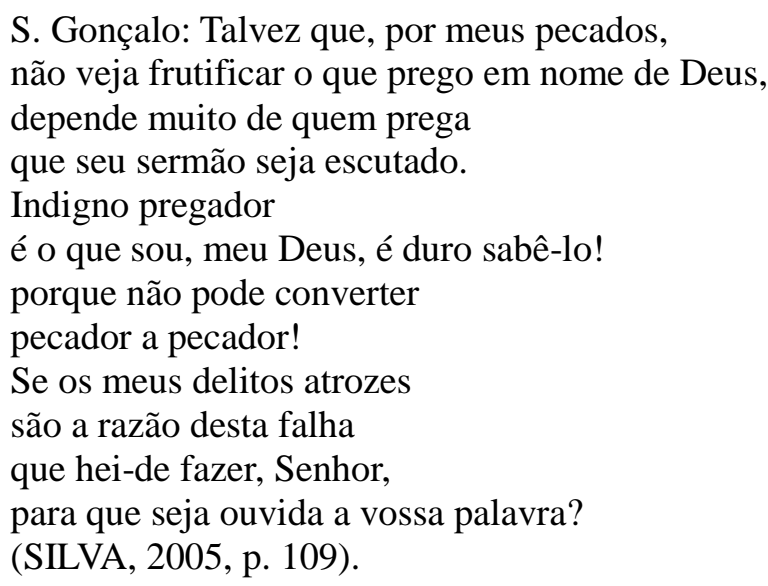

A resposta é a partida para Jerusalém. O templo, que tantas vezes foi destruído e reconstruído, representa, na concepção judaica a "cópia de um arquétipo celeste" (ELIADE, 1992, p. 55). Na concepção do cristianismo, tal ideia não é diferente. Para que se possa compreender claramente o que significa o termo arquétipo e, portanto, a importância da cidade para cristãos, judeus e muçulmanos, é preciso recorrer aos estudos de Jung, que afirma que o conceito de arquétipo, que constitui um correlato indispensável da ideia do inconsciente coletivo, indica a existência de determinadas formas na psique, que estão presentes em todo tempo e em todo lugar. (JUNG, 2008, p. 53).

Convém esclarecer que, de acordo com Jung, o ego representa o centro da consciência, já o inconsciente apresenta-se de duas formas distintas: inconsciente pessoal e inconsciente coletivo. Resumidamente, o inconsciente pessoal é representado pela parte da nossa vida que envolve nossas vivências e foi esquecido ou reprimido, é onde se encontram a maioria dos complexos. Em contrapartida, os conteúdos do inconsciente coletivo nunca foram conscientes, são estruturas herdadas, que chamamos de arquétipos.

O inconsciente coletivo é uma parte da psique que pode distinguir-se de um inconsciente pessoal pelo fato de que não deve sua existência à experiência pessoal, não sendo, portanto uma aquisição pessoal (...). Enquanto o inconsciente pessoal consiste em sua maior parte de complexos, o conteúdo do inconsciente coletivo é constituído essencialmente de arquétipos. (JUNG, 2008, p. 53).

No entanto, os arquétipos podem tornar-se parcialmente conscientes e aparecerem, sob 
a forma de imagens, nos sonhos, nos contos de fadas, nos mitos e também nas obras de arte, como a poesia. É importante ressaltar que, para Jung, a psiqué é a imagem e a imagem é a realidade, ou seja, o que muitos consideram como "apenas imaginação" é a própria atividade psíquica.

Assim, considerando-se as noções de inconsciente coletivo e arquétipo, constata-se que Jerusalém é a representação do primeiro arquétipo, ou imagem primordial, a existir na mente humana: Deus. "Como a palavra Deus perdeu seu crédito para muitos, por causa das tolices inaceitáveis que têm sido ditas e feitas em "Seu" nome, talvez seja melhor substituí-la pelo termo sagrado" (ARMSTRONG, 2011, p. 14). Dessa forma, o reencontro com o sagrado será essencial para que a vida de São Gonçalo ganhe um sentido diferente.

Ao se falar da busca de São Gonçalo pela divindade, não se pode deixar de fazer referência ao mito. Como já foi dito anteriormente, ele é, também, uma forma de expressão dos arquétipos. O mito não é uma fábula, uma lenda ou uma invenção, ele é sempre uma representação coletiva e explica fatos atuais através de acontecimentos primordiais. Por meio do rito estabelece-se essa conexão (atual e primordial) e o homem pode dar orientação a sua vida. Karen Armstrong define mito da seguinte forma:

\footnotetext{
Os mitos mais fortes se relacionam com o extremo; eles nos forçam a ir além de nossa experiência. Há momentos em que nós todos, de um modo ou de outro, temos de ir a algum lugar aonde nunca fomos e de fazer o que nunca fizemos. O mito trata do desconhecido; fala a respeito de algo para o que inicialmente não temos palavras. Portanto, o mito contempla o âmago de um imenso silêncio. (ARMSTRONG, 2005, p. 09).
}

Não se fala na peça quanto tempo São Gonçalo se demora em Jerusalém. Sabe-se que ele partiu em busca do desconhecido, do mito do Paraíso, da criação, da união perfeita entre deuses e homens. Ir em busca do mito é ir ao encontro de si mesmo, assim, após essa busca, o santo retorna a Portugal sem avisar, feliz e emocionado:

S. Gonçalo: Agora que da Santa Cidade de Jerusalém regressei, vi, percorri e admirei com a mais rendida humildade o seu divino santuário onde o nosso redentor alardeou o seu amor no palco do Calvário. De novo conosco vive o vosso amigo, o vosso abade. De novo a flor da verdade 
ganhará o seu vigor, convosco outra vez estou, meus pobres, feliz missão. (SILVA, 2005, p. 173).

No entanto, Gonçalo não é bem recebido pelo sobrinho, que havia espalhado pela região o boato de que o tio estaria morto. Antônio havia desistido do sacerdócio e vivia, juntamente com Rosaura, do dinheiro da igreja. A volta inesperada do tio era contrária aos seus planos e, sentindo que sua vida desregrada chegava ao fim, Antônio dá uma surra no tio:

S. Gonçalo: Bate-me mais, ainda é pouco, ante os suplícios me ajoelho, muito mais padeceu Cristo em sua amarga paixão. (SILVA, 2005, p. 181).

São Gonçalo, expulso de sua casa pelo sobrinho, passa a vagar pela cidade como um mendigo. Após buscar abrigo nos penhascos, triste e decepcionado, entra em contato com o sagrado por meio da aparição de Nossa Senhora, que lhe indica um caminho possível para a resolução de seus problemas:

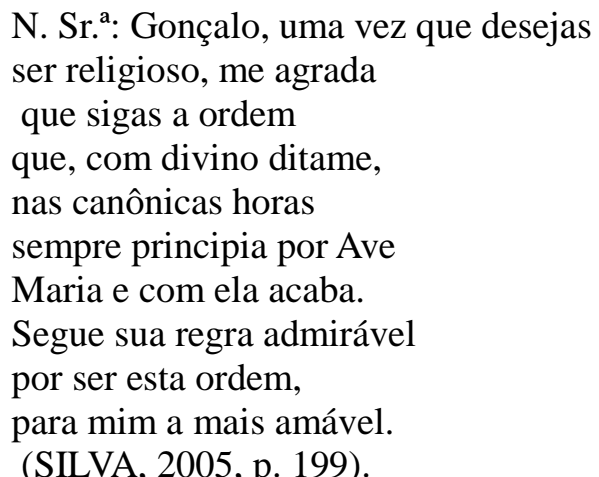

Nossa Senhora refere-se à ordem dos dominicanos, a qual São Gonçalo deverá procurar a fim de encontrar abrigo. Percebe-se o quanto sua ida à cidade de Jerusalém foi importante, a ponto de fazer com que São Gonçalo pudesse ter contato direto com seres divinos, recebendo de Nossa Senhora um conselho, mesmo estando em um ambiente profano. Assim, São Gonçalo volta a falar aos seus fiéis, no entanto, muitos não conseguem ir ao encontro dele em virtude da impossibilidade de atravessarem o rio Tâmega. Vários fiéis, na tentativa de fazê-lo, morriam afogados. Sentindo-se incapaz de resolver o problema, o santo clama a Deus e um anjo aparece: 
Entra um anjo: Gonçalo, não te preocupes que a tua prece chegou ao Empíreo. Sendo como fogo em línguas separado o Supremo Senhor o ouviu.

E eis que, diligente, encaminha a construção da ponte, a este ponto, ainda que consideres impossível tudo a deus é possível. Demovendo os duros corações para que te façam grandes dádivas, deste modo verão que Deus, na sua obra, soube dar cumprimento aos teus desejos. (SILVA, 2005, p. 251).

Inicia-se, assim, a construção de uma ponte sobre o rio Tâmega. No entanto, o contato com o mundo celeste não se resume apenas à aparição de Nossa Senhora e do anjo. São Gonçalo realiza um milagre ao fazer com que dos penhascos de onde se constrói a ponte, jorre vinho para que os trabalhadores se saciem.

São Gonçalo: Eia! Que por falta de vinho não se suspenda a obra!

Bendito seja o Senhor,

Que não falta a quem lhe pede.

(SILVA, 2005, p. 265).

Ao fim da peça, São Gonçalo perdoa o sobrinho Antônio e também Rosaura, e ambos passam a levar uma vida monástica. A fim de que todos esses acontecimentos pudessem ser realizados, foi de grande importância a viagem de São Gonçalo do Amarante a Jerusalém. A cidade foi capaz de lhe proporcionar a verdadeira santidade, revelada por meio da humildade, da fé em Deus e do perdão aos pecadores. Dessa forma, o próprio santo assemelha-se às virtudes da cidade, sendo elevado aos céus, ao lado de Nossa Senhora: "Crucial para o culto de Jerusalém, desde o início, é a importância da caridade concreta e da justiça social. A cidade só pode ser santa se for também justa e compassiva com os fracos e os indefesos". (ARMSTRONG, 2011, p. 20).

\section{CONSIDERAÇÕES FINAIS}

É possível constatar que o mito também é responsável pelo significado que as pessoas dão às representações. Em outro ensaio de Olhos de madeira: nove reflexões sobre a distância, intitulado Mito: distância e mentira, Ginzburg (2001), nos alerta que o mito 
também pode ter a finalidade de manipular a realidade, pois cada época inventa o seu mito, e ele também pode forjar o que vem a ser a representação da realidade. Quando o cristianismo, na Idade Média, propôs a adoração de imagens, ao que a Igreja Católica renomeou como veneração, o fim era manter o controle e preservar as distâncias existentes entre as diversas classes sociais. No entanto, para as pessoas que creem no santo como representação do sagrado, tais reflexões não são levadas em conta.

É de se estranhar que Antônio José da Silva tenha dado importância a um santo em uma de suas peças. Isso porque, sendo cristão novo, não se esperava que ele ressaltaria os valores de São Gonçalo numa comédia. No entanto, não se podemos esquecer que o Judeu utilizava de meios que, para a época, eram capazes de possibilitar sua crítica, ao mesmo tempo em que a camuflaria.

Assim, o Judeu escolheu um santo que, embora fosse muito respeitado em Portugal, trazia em si o comportamento que era contrário ao da Igreja Católica na época: era capaz de conviver com as diferenças e de exercer a tolerância, além disso, privilegiava a alegria, a festa e as danças, ao contrário do Tribunal do Santo Ofício, que espalhava a tortura e o medo sobre Portugal e Espanha. Por meio da história do santo, Antônio José pôde expressar seu descontentamento quanto à intolerância religiosa da época.

Para os que creem nos milagres de São Gonçalo, é interessante notar como as palavras de Ginzburg relativas à representação aplicam-se à imagem do santo. Ao evocar a ausência ou sugerir a presença (GINZBURG, 2001), os fiéis contemplam, por meio da imagem, um intermediário do sagrado que se encontra no Céu, e que é capaz de ouvir suas orações e leválas a Deus.

Fica claro que eles não veem na imagem a presença concreta do santo, mas sim o que ela representa, de acordo com a identificação que cada um tem com o São Gonçalo do Amarante. Conslui-se, dessa forma, o quanto o cristianismo, durante a Idade Média, foi importante para trazer até os dias de hoje o conceito de representação: abstraindo-se a imagem, adora-se o que ela representa, e não o que ela é.

\section{REFERÊNCIAS}

ARMSTRONG, Karen. Breve história do mito. Tradução de Celso Nogueira. São Paulo: Companhia das Letras, 2005.

Jerusalém: uma cidade, três religiões. Tradução de Hildegar Feist. São Paulo: Companhia das Letras, 2011. 
CASCUDO, Luís da Câmara - Dicionário do Folclore Brasileiro. RJ: MEC, 1962.

CHARTIER, Roger. História Cultural - Entre práticas e representações. Lisboa/Rio de Janeiro: Difel/Bertrand Brasil, 1990. 1991. O mundo como representação. In: Estudos Avançados, Rio de Janeiro, n.11(5), ELIADE, Mircea. Aspectos do Mito. Lisboa: Edições 70, 1963. 1992. O sagrado e o profano. Tradução de Rogério Fernandes. São Paulo, Martins Fontes,

GINZBURG, Carlo. Representação: a palavra, a ideia, a coisa. In: Olhos de madeira: nove reflexões sobre a distância. Tradução de Eduardo Brandão. São Paulo: Companhia das Letras, 2001.

JUNG. Carl Gustave. Psicologia e poesia. In: O espírito na arte e na ciência. Petrópolis, Vozes, 1985.

SANTOS, Beatriz Catão Cruz. A Festa de São Gonçalo na Viagem em Cartas de La Barbinais. Via Spiritus, Porto, ano 11, n. 11, p. 221-238, 2004.

SILVA, Antônio José da. (1705-1739). O Judeu em cena: el prodígio de Amarante. Organização, apresentação e cronologia Alberto Dines; transcrição do manuscrito, versão para o português e notas Victor Eleutério. 1. Ed. Bilíngue e comprovação de autoria. São Paulo; Edusp, 2005.

VENDRAMINI, Maria do Carmo. A dança de São Gonçalo em Ibiúna. In Revista Brasileira de Folclore, SP: maio/agosto de 1976, ano XIV, nº 41, p. 45-74.

VIEIRA, Antônio. “Sermão de São Gonçalo”. Sermões. Porto: Lello \& Irmão, 1959, v-2. 